"a glorious gift of God," but is it not seemly in age that it should be so ? A wise old bachelor physician, whose clerk I had once been, said to me-still young-how good it was at last to be free of the pesterings of sex. May not even Dr Comfort live to say the same?

LINDSEY W BATTEN

Westerham, Kent

theless, that bumetanide was able to produce a diuresis of over 81 in the presence of such widespread thrombosis of the renal vasculature is surprising.

Our experience indicates that bumetanide is an effective alternative to frusemide in the seriously ill patient with acute renal failure.

We thank Dr T Low-Beer, Selly Oak Hospital, Birmingham, for allowing us to report this case.

T E G JONES

\section{Still dissolving discs?}

SIR,-Do the young men still read the $B M \mathcal{F}$ (apart from job advertisements)? If so, what will they make of the conclusion to this otherwise interesting leading article (29 October, p 1107)? "At present, therefore, there seems to be a genuine choice for the patient with classical disc herniation. Chemonucleolysis is quicker but operation surer and the relative safety arguable."

Will they doubt their senses when they see $95 \%$ of our patients recovering with rest and exercises at the proper time, perhaps with a little traction and with complete safety?

E SHEPHARD

West Kent General Hospital,

Maidstone
Mast Kent

\section{Bumetanide in acute renal failure}

SIR, - Though bumetanide has been in widespread use over recent years as an oral diuretic, there is little information on its intravenous use at high dosage and none on its use in the treatment of acute renal failure. The following somewhat unusual case report may therefore be of interest.

A 78-year-old man was admitted with a 4 -h history of central chest pain and collapse. An electrocardiogram showed inferior myocardial infarction and this was associated with cardiogenic shock, aortic thrombosis-absent right femoral and diminished left femoral pulse-and acute renal failure.

His serum sodium concentration was normal His serum potassium concentration at one stage was $7 \mathrm{mmol}(\mathrm{mEq}) / \mathrm{l}$, though this became normal subsequently. His blood urea level was normal on admission, but gradually rose to $75 \mathrm{mmol} / \mathrm{l}$ $(452 \mathrm{mg} / 100 \mathrm{ml}) 12 \mathrm{~h}$ before death. The serum aspartate transaminase and hydroxybutyrate dehydrogenase activities were typically elevated. Chest $x$-ray revealed pulmonary oedema and marked left ventricular hypertrophy.

He was initially given frusemide $120 \mathrm{mg}$ intravenously, but remained anuric. He was then given bumetanide $6.25 \mathrm{mg}$ intravenously every $4 \mathrm{~h}$ by constant infusion pump over 40-min periods. This regimen was continued for $113 \mathrm{~h}$, during which he was given $176.8 \mathrm{mg}$ of bumetanide (representing $37 \mathrm{mg} / 24 \mathrm{~h}$ ). During this period he improved clinically and produced no less than $8035 \mathrm{ml}$ of urine. Because no further supply of bumetanide was available the patient was switched to intravenous frusemide. His condition deteriorated and he died. He was given $1000 \mathrm{mg}$ of frusemide over $25 \mathrm{~h}$ over the last hours of life, producing $1500 \mathrm{ml}$ of urine.

The most interesting feature of this case is that at necropsy almost total antemortem arterial thrombosis was demonstrated. In particular, the renal arteries were nearly totally occluded and the renal tissue.contained multiple large infarcts.

For renal failure to occur virtually the entire nephron population of both kidneys must be deprived of blood supply. ${ }^{1}$ Never-
Manchester Victoria Memorial Jewish Hospital,
Manchester

General Hospital

George Kurien

Birmingham

'Bricker, N S, in Cecil-Loeb Textbook of Medicine, ed $\mathrm{P} B$ Beeson and $\mathrm{W}$.

\section{Shortage of radiologists}

SIR,-I read with great interest the letter from could not agree more with him that the shortage of radiologists has been a big problem, and perhaps the real volume of the problem will be known in the near future after the new contract has been negotiated. Compared with many other district general hospitals, I have no doubt that Frenchay Hospital is far better equipped, and if he is finding difficulty in getting the consultant jobs filled in his centre I wonder what chances there are for departments which are not so well equipped. If in Bristol, where there is an established, wellknown teaching centre for radiology, there is such difficulty that two out of four consultant jobs are vacant the situation elsewhere can well be imagined without my having to elucidate this point.

There are two main reasons why there is a shortage of radiologists. In the first instance the job satisfaction is not always present in all departments; and in the second the financial return is going to be gradually less and less, compared with our clinical colleagues, when the new contract is negotiated. I think I am voicing the opinion of many of my colleagues in radiology that promises have been made to many of us in regard to improvisation or creation of a new $x$-ray department altogether for several years, and nothing has happened in many instances. It is not unlikely that some of my colleagues will retire with the dream of their hearts unfulfilled, having toiled under difficult and demanding circumstances. After the successful negotiations of our junior medical colleagues those who happen to be in clinical medicine or surgery can earn substantially more than those who have chosen radiology as their future career. All of us know what an absurd and chaotic situation has been created by a senior registrar in clinical subjects being in a position to earn more money than a newly appointed consultant. Our junior colleagues are far more realistic than most of us in the older generation group, and that accounts for the increasingly lesser number of people taking up radiology as a career, where the monetary return is less likely to be as large as in clinical specialties.

It is a well-known fact that in EEC countries and also in North America and, lately, in the Middle Eastern countries radiologists are in a position to earn substantially more than they Dr J L G Thomson (5 November, p 1225). I can earn in Britain. There has been a steady drain of radiologists trained fully to take up consultant positions at the cost of the ratepayers of this country; this is inevitable, and unless something is done to counterbalance this situation the brain-drain, I fear, cannot be stopped. No matter how much we may talk about the morality of the practice of medicine, the realities of the present day have to be faced. In these days of inflation and rising cost of living radiologists cannot forget that they also have their financial commitments which they have to live up to. When they find that they are not in a position to cope with the situation or they can do substantially better by crossing the English Channel or the Atlantic I do not think that they can be blamed if they emigrate.

I have full confidence in the negotiators of the BMA, but I must say that I am a bit disappointed that, when a lot of commotion was created over the phasing out of pay-beds and private practice in hospitals and a lot of talks are still going on in regard to free time, the same degree of importance or emphasis does not seem to have been given to the shortsupply specialties like radiology. It will be a very sad situation if the negotiators come to achieve a satisfactory contract with the Government but are faced with a National Health Service from which the radiologists have drained out because their interests had not been looked into in the manner in which they deserve.

It is needless to say that radiology of today is not exactly what radiology used to be 10 or 15 years ago. Radiologists today are clinicians who use their radiological knowledge in making a diagnosis to assist their clinical colleagues in the management of their cases. I would very strongly feel that one method of keeping radiologists in the country would be the introduction of an inducement bonus to compensate for the impossibility of establishing in private practice on account of the enormous costs involved and also for the limited number of domiciliary consultations.

In conclusion, I would like to say that if our clinical colleagues would like to take full advantage of modern radiology and if patient care is the primary concern of the Government, then adequate steps must be taken so that the emigration of the radiologists from this country is not only stopped but reversed.

P K GANGULI

Department of Radiology,

Mid Glamorgan Area Health Authority,

East Glamorgan Health District,

Church Village,

Nr Pontypridd, Glamorgan

\section{Functional budgeting}

SIR,-I write with reference to the Association's statement on functional budgeting (12 November, p 1299). As treasurer to a large London teaching district I am both puzzled and concerned by the assertion that under functional budgeting procedures in many instances the budget holder for medical and paramedical services is other than the relevant consultant/head of department. Unsatisfactory though this arrangement is, it is surely unpardonable if it has been countenanced without reference to the appropriate consultant, etc. Such an arrangement is, in my judgment, alien to the spirit and the letter of functional budgeting.

Before reorganisation budgets in the main in the Health Service were input-orientated. In 
other words expenditure was classified subjectively - for example, salaries and wages for the whole organisation-with insufficient regard to objectives and service analysis. Budgets tended to be controlled by teams, and managers physically charged with recruiting staff, ordering goods and equipment, or commissioning work were not always accountable in the budgetary control sense. This is not to suggest that control did not exist but merely that it was sometimes exercised by the wrong people. Functional budgeting properly handled is geared to overcome these deficiencies. Under this system responsibility is allocated to individuals but with a bias on the type of activity managed rather than a particular unit or, for that matter, a special location or area. Responsibility for the budget should be placed in the hands of the individual who is charged with orchestrating that particular service. If this is the consultant, then the budget should accrue to him.

In my experience an immediate and major payback from the development of functional budgeting has been the evolvement of a much closer relationship between medical staff and finance service staff. In my district budget holders are involved in the budgeting process from the very outset and are actively assisted by finance staff in identifying the financial implications of the various proposals. This participation leads to the budget becoming the framework within which each manager discharges his particular responsibility.

I frequently stress to my staff the importance of recognising that many of our budget holders are highly skilled professionals, be it for their skills in medicine, nursing, engineering, and so on. They, however, would probably readily acknowledge that finance and administration is not their forte. In these circumstances the method of presenting information is paramount. The finance service must strive to concentrate the energy of controllers on the key problem areas by avoiding the production of a mountain of paper steeped in jargon which the accountants themselves at times find offputting to peruse.

D P F BEGLEY

Kensington and Chelsea and

Westminster Area Health Authority,

South District,
London SW1

\section{Work of community physicians}

SIR,-As you are aware (5 November, p 1226), a working party of community physicians is considering the current state of the specialty of community medicine and how it compares with pre-1974 expectations. The membership of the working party is drawn mainly from the Central Committee for Community Medicine of the BMA and the Board of the Faculty of Community Medicine.

The Centre for Extension Training in Community Medicine in association with the working party is undertaking a survey of the work of community physicians and community medicine specialists in the United Kingdom. It has been decided that the most effective way to gather the necessary type of information is by means of a diary-keeping a record of all activities undertaken during one full week. The period chosen is Monday 5 December to Sunday 11 December inclusive.

All community physicians and community medicine specialists should receive these diaries by 30 November. Anyone in an established post in community medicine who has not received a copy of the diary by that date should contact Dr R G Donaldson, Centre for Extension Training in Community Medicine, 31 Bedford Square, London WC1B 3EL; telephone 01-636 7382

At the same time all trainees in community medicine will be receiving a questionnaire from Dr Spencer Hagard. Anyone who has not received this by now should contact him direct at 396 Milton Road, Cambridge CB4 1SU; telephone Cambridge 54970.

G D DUNCAN Working Party on the State of BMA House, London WC1 Community Medicine

\section{Functions of hospital occupational} health medical officers

SIR,-In your issue 29 October, $p$ xix, you publish an advertisement for a medical officer in occupational health at the Royal Marsden Hospital, London and Surrey.

I am surprised to note that the medical officer will be required to examine staff "with regard to... employers' liability in terms of industrial injury." Such examinations form no part of the duty of an occupational health medical officer but are a management function. The functions of the hospital occupational health medical officer are clearly stated in the Tunbridge Report of $1968^{1}$ and in the draft circular on occupational health which the Department of Health and Social Security has recently sent to area health authorities.

I think it is important that new occupational health departments are started on the right lines and this can be done only by the appointment of physicians or nurses, or both, who are experienced in occupational health.

\section{Good Hope General Hospital,
Sutton Coldfield, Warwicks}

D M SMITH

The Care of the Health of Hospital Staff. Report of the Joint Committee of the Central and Scottish
Services Councils. London, HMSO, 1968.

\section{Consultant contract}

SIR,-Current negotiations to do away with the part-time bonus for whole-time consultants in a 10-session contract (Guardian, 14 November, p 1) may do the profession a gross disservice.

There are two basic pitfalls. The decision to pay for extra sessions (and thereby increase income) will lie with the area or regional authority, which is unlikely to be liberal when requests for extra sessions are to be found from their already restricted budget. The current system of NHS funding via regiona allocation does not allow for more than a single topping-up of regions' budgets. When the contract appears, apart from this the contract will not be priced until after it is agreed, thereby allowing the Review Body to give even greater weight to possible private practice earnings than they do at present because every consultant will now have the right to do private practice and a free session per week. The rate per session will almost certainly be comparatively reduced when potential private practice earnings are assumed to be universal.

That's not all. Those doing private work Worthing, Sussex now will face greater competition and the profession will have a built-in interest in developing the private sector at the expense of the NHS. Full-timers will be forced to seek private work to survive. It is unlikely that the Department of Health and Social Security will make the same mistake twicewe may find the tide of UMTs turned topsyturvy. Encouraging a substantial part of the consultant body to remain full-time could prove to be the best assurance that the rate per session to all consultants is not further undervalued. Department of Psychiatry,
Charing Cross Hospital,

STEVEN HiRsCh

London W6

\section{Justice for the younger consultant}

SIR,-As one of the "junior" consultants selectively penalised by the increments freeze I endorse the sentiments expressed in $\mathrm{Mr} \mathrm{J} \mathrm{M}$ Shennan's letter (22 October, p 1089). It was a multifactorial injustice too complicated to hold the attention of anyone it didn't affect; none the less, considering that increments anyway were never even the inflation-provoked pay rises the incomes sanctions were invoked to prevent, the profession's failure to protect those swindled was infinitely saddening. We were offered instead as a sacrifice on the altar of egalitarianism to atone for the bourgeois guilt of the medical establishment.

Now a new contract is imminent. From all the conflicting interests and opinions surely one truth emerges: if we are to continue to be paid directly by the Government we must obscure the annual amount to prevent its emotional deployment against us in the public arena by left-wing politicians and a hostile press. To this end sessional payments would be best, "priced" or not; certain fees-forservice should. exist in addition.

Meanwhile $\mathrm{Mr}$. Shennan dislikes the pejorative "junior" to describe his status, and so do I. He offers instead "cut-price" or "discount." While apt, his terms are unwieldy. "Junior consultant" could be contracted to "insultant," deriving from insultee-one who is insulted. Better still, increments should be scrapped.

Gloucestershire Royal Hospital,

H Thomson Gloucester

\section{General practitioners' work load}

SIR,-With reference to the letter from $\mathrm{Dr}$ $M$ J Critchley (5 November, $p$ 1226), one way in which the GP's work load has been increased recently stems directly from the "economy" measure of the hospital pharmacist issuing minimal quantities of drugs.

I have had two instances in one surgeryone a man sent home from the accident department of one of our local hospitals after a knee injury with only six analgesic tablets, the other a patient discharged from hospital after an operation who had been found to have iron-deficiency anaemia, who had been dispensed seven days' supply of an oral iron preparation. In both cases there was no other reason for their wanting to see me.

What sort of "economy" is this?

ARCHIE BEATSON 